\title{
The financial condition of corporations of the Russian defense-industrial complex, which are included in the TOP lists of the largest military companies in the world
}

\author{
Elena Gregova, ${ }^{1}$ Irina Tulyakova ${ }^{2}$ and Victor Dengov ${ }^{2, *}$ \\ ${ }^{1}$ University of Zilina, Faculty of Operation and Economics of Transport and Communications, \\ Department of Economics, Univerzitna 1, 01026 Zilina, Slovakia \\ ${ }^{2}$ Saint Petersburg State University, Faculty of Economics, Department of Economics \& Economic \\ Policy, University embankment 7-9, 199034, St Petersburg, Russia
}

\begin{abstract}
Research background: Over the recent period, new "players" have appeared on the world arms and military equipment markets as large exporters, which were previously positioned as large importers of weapons. As international experience shows, in order to become a global exporter of weapons and military equipment, one needs to create powerful military companies. Russian defense companies occupy high places in various TOP lists, which provides the country with a stable position in the export markets. An analysis of the financial condition of these companies makes it possible to deepen the assessment of the prospects for Russian arms exports. The authors have repeatedly addressed the topic of Russian arms exports and the place of Russia in the global arms and military equipment trade markets.

Purpose of the article: The main goal of the study is to analyze the current financial standing of the leading Russian defense industry companies, which ensure the country's stable positions in global export markets.

Methods: Generalizations of the research are based on the processing and systematization of data obtained from available information sources. By analyzing the statistics, the authors were able to deduce the trends of the current moment and determine the prospects.

Findings \& Value added: Consideration of the financial condition of backbone enterprises of the Russian defense industry enabled the authors to make an educated guess about what the prospects for Russia hold high positions in the global markets of AME.
\end{abstract}

Keywords: military state corporations; the financial condition of defense companies; world exports and imports of weapons and military equipment

JEL Classification: F14; L64; O57

\footnotetext{
*Corresponding author: v.dengov@spbu.ru
} 


\section{Introduction}

The global arms trade markets are highly competitive. Along with the military-political aspect, global players such as the United States, Russia, and the EU see them as a large and stable source of cash income (Blum, 2019; Tulyakova et al., 2017; Dengov et al., 2018; Tulyakova \& Dengov, 2018; Tulyakova et al., 2019). Although the positions of the top three players in these markets are still quite stable, new players, formerly large importers of weapons, are trying to win back a part of the arms export market. First of all, we are talking about such countries as China (PRC), Japan, Saudi Arabia, UAE, India (Tulyakova, 2016; Dengov et al., 2021). They began to accelerate the creation of their own large companies for the production of certain types of weapons and some of them were quite successful in this business. Of course, the success of any country in the global arms export market is determined by the number and size of its arms manufacturing companies, their place in the Top Lists. The changing situation among the leading arms companies can be observed in the annually published lists of the largest military companies. The most authoritative sources of this information include SIPRI and Defence News.

According to the Defence News website (2020), the first places in the TOP-100 are traditionally occupied by US companies. There are only 38 of them, and the share of the cost of the created products is more than $50 \%$. The United States has been and remains the main producers of weapons and military equipment. Lockheed Martin alone creates \$ 53,230 million worth of products per year. according to SIPRI data. And this is $14.5 \%$ of all that is created by the 25 largest companies in the world. Lockheed Martin has been at the top of the ranking for almost 20 years (since 2003). European companies are widely represented in this list (Bitzinger et al., 2017).

The emergence of open data on the PRC has led to the fact that in the top lists of recent years, Chinese firms are at the top of the list. The top 100 includes 8 companies from the PRC at once, and all of them are in the top twenty. But just a few years ago, some wellknown experts in this field believed that the efforts of the Chinese government "had little positive impact on the country's military technological and industrial capabilities" (Bitzinger, 2016). A distinctive feature of Chinese large military corporations is that military products account for only about $30 \%$ of total revenues, which indicates a high diversification. Therefore, to speak about the insufficient efficiency of the Chinese military market (Wang et al., 2019), in our opinion, is at least controversial. For example, the Aviation Industry Corporation of China (6th in 2019) of almost $\$ 67$ billion in total revenue, 38\% comes from military sales. A similar situation is with China Aerospace Science and Industry Corporation (32\%), China Shipbuilding Industry Corporation (20\%). For comparison, the Russian company Almaz-Antey, which is always in the tops in high places, has $95 \%$ of its total revenue from military sales. Ranked 35, the Russian company Tactical Missiles Corporation JSC receives $98 \%$ of its revenue from military sales.

Recently, in addition to European, American and Russian companies, more and more companies from Asia, namely Japanese and South Korean companies, have been on the top lists.

The desire to become independent from foreign suppliers, the high demand for weapons and financial capabilities lead to the creation of new national defense companies. In particular, in the Middle East, these are the UAE and Saudi Arabia. In the Top 25 SIPRI for 2019 , for the first time, EDGE from the UAE was in 22nd place with $95 \%$ of military sales of total revenue (about $\$ 5$ billion). Saudi Arabian Military Industries (SAMI) was established in 2017. The agreements it concluded on joint production with US, EU and Russian companies, the transfer of technology and the localization of production in the country should lead to the fact that this company will soon also be included in the top lists of world arms manufacturers. This approach may become one of the main trends in the near future. Back in 2014, a number of specialists built an agency simulation model for the development of the European defense industry. "The simulation analysis points out that European defense firms 
will progressively become more efficient, less dependent on public procurement and innovation policy support, and more prone to knowledge sharing and inter-firm collaborations. This firm-level dynamics will in the long-run lead to an increase in the industry's export propensity and a less concentrated export market" (Blom, et al., 2014).

\section{Methodology, databases and analytical sources of research}

The statistics for the analysis were taken from databases of think tanks, which rely mainly on information from open sources or data obtained on a voluntary basis from the manufacturers themselves. It should be noted that this is why it is difficult to draw a completely realistic picture from the top lists. Since the financial component is often classified information, agencies devise their own differing valuation methods. At the same time, the use of various mechanisms for calculating and determining prices for different types of weapons leads to a significant discrepancy in figures. Therefore, in one study it is necessary to mainly use data from only one or two agencies. In addition to the already mentioned Defense News website, we mainly used SIPRI data when conducting international comparisons. This allows, without having $100 \%$ reliable figures, at least to observe the main trends. The statistics provided by this agency are used by many researchers, are completely open, but have their own specific assessment methodology (Fleurant and Tian, 2018).

There are several analytical agencies in Russia. Taking into account the area of this research, when analyzing the financial condition of the leading Russian military corporations, we used the information provided by the system of professional analysis of markets and companies, created by the Interfax Group.

Statistical methods and methods of system analysis are used in this article as analysis tools.

\section{Results}

At the previous stage of reforming the Russian defense-industrial complex through centralization and integration, corporations were formed that became practically monopolists in their sphere of military production. Along with industry corporations (such as the United Aircraft Corporation (UAC), United Shipbuilding Corporation (USK), etc.), it was announced the creation of state corporations such as Rostec.

State corporations and large industry corporations are similar in that in fact they represent the most complex form of corporate integration, characterized by a high degree of nesting of managed structures. For example, the state corporation Rostec includes the Oboronprom Corporation, which, in turn, includes the holding company Russian Helicopters, which includes enterprises of the helicopter industry, for example, OJSC Kamov. As another example, we can cite the industry corporation OJSC "UAC", which has an equally complex structure. UAC OJSC includes, for example, the Sukhoi Aviation Holding Company, which includes, among other things, the Irkut Corporation, which is a vertically integrated holding, one of whose enterprises is the Irkutsk Aviation Plant.

State corporations and large industry corporations can be considered as a single group of objects that implement similar tasks.

In general, it can be noted that the reforms carried out made it possible to reduce the cost of production, increase revenues, form mechanisms for the effective use of profit on investments in the development of a new generation of both military and civilian equipment, modernize the production apparatus and develop new export markets.

If we talk about the place of Russian military corporations in the world rankings, then first of all it should be borne in mind that they do not take into account state corporations like Rostec. At the same time, Russia is not as widely represented in the TOP-100 of the world's largest military companies as, say, the United States. According to the latest available data 
from SIPRI (2018), this list included 41 American corporations and only 10 Russian ones. (SIPRI did not provide data on Chinese corporations for 2018). Since 2019, data on Chinese corporations has appeared in the TOP-25 from SIPRI, which significantly changed the situation in the ranking (TOP-25) (see Table 1).

Table 1. The SIPRI top 25 arms-producing and military services companies in the world, 2019 (in millions of US dollars)

\begin{tabular}{|c|l|c|c|c|c|}
\hline $\begin{array}{c}\text { Rank- } \\
\mathbf{2 0 1 9} \\
\mathbf{2 0 1 8})\end{array}$ & Company & Country & $\begin{array}{c}\text { Arms } \\
\text { sales } \\
\mathbf{( 2 0 1 9 )}\end{array}$ & $\begin{array}{c}\text { Total sales } \\
\mathbf{( 2 0 1 9 )}\end{array}$ & $\begin{array}{c}\text { Arms sales as } \\
\text { a \% of total } \\
\text { sales (2019) }\end{array}$ \\
\hline $1(1)$ & Lockheed Martin Corp. & US & 53230 & 59812 & 89 \\
\hline $2(2)$ & Boeing & US & 33580 & 76559 & 44 \\
\hline $3(3)$ & Northrop Grumman Corp. & US & 29220 & 33841 & 86 \\
\hline $4(4)$ & Raytheon & US & 25320 & 29176 & 87 \\
\hline $5(6)$ & General Dynamics Corp. & US & 24500 & 39350 & 62 \\
\hline $6(5)$ & AVIC & China & 22470 & 66846 & 34 \\
\hline $7(7)$ & BAE Systems & UK & 22240 & 23378 & 95 \\
\hline $8(9)$ & CETC & China & 15090 & 32951 & 46 \\
\hline $9(8)$ & NORINCO Group & China & 14540 & 65929 & 22 \\
\hline $10(-)$ & L3Harris Technologies & US & 13920 & 18074 & 77 \\
\hline $11(14)$ & United Technologies Corp. & US & 13100 & 77046 & 17 \\
\hline $12(11)$ & Leonardo & Italy & 11110 & 15432 & 72 \\
\hline $13(10)$ & Airbus & Trans-European & 11050 & 78905 & 14 \\
\hline $14(13)$ & Thales & France & 9470 & 20601 & 46 \\
\hline $15(12)$ & Almaz-Antey & Russia & 9420 & 9657 & 98 \\
\hline $16(16)$ & Huntington Ingalls Industries & US & 7740 & 8899 & 87 \\
\hline $17(38)$ & Dassault Aviation Group & France & 5760 & 8219 & 70 \\
\hline $18(18)$ & Honeywell International & US & 5330 & 36709 & 15 \\
\hline $19(19)$ & Leidos & US & 5330 & 11094 & 48 \\
\hline $20(22)$ & Booz Allen Hamilton & US & 5140 & 7464 & 69 \\
\hline $21(28)$ & General Electric & US & 4760 & 95200 & 5,0 \\
\hline $22(-)$ & EDGE & UAE & 4750 & 5000 & 95 \\
\hline $23(23)$ & Rolls-Royce & UK & 4710 & 19732 & 24 \\
\hline $24(25)$ & CSGC & China & 4610 & 29065 & 16 \\
\hline $25(21)$ & United Shipbuilding Corp. & & & & 83 \\
\hline & & & 5500 & 5416 & \\
\hline
\end{tabular}

Source: SIPRI (2021)

4 Chinese corporations entered the list of the 25 largest corporations at once, including 3 in the top ten. There are only two Russian corporations in the TOP-25 - Almaz-Antey and USC, while a year earlier there were 3 of them (also UAC). Of the 25 largest military corporations in the world, almost half (12) are American, but Chinese companies may squeeze them out in the coming years.

As for the rest of the Russian military corporations from the TOP-100 (2018), their position can be observed according to the data in Table. 2 .

If in general for 5 years (from 2013 to 2018) the representation of Russia in the TOP-100 has practically not changed, then most of our companies have lost several positions in the world ranking. The reasons for this may be different - both the global economic crisis and the sanctions of Western countries and the inclusion of Chinese companies in the world rankings. When data for 2020-2021 becomes available, it will also be possible to assess the impact of the COVID-19 pandemic. 
Table 2. Places of Russian military companies in the SIPRI Top 100 arms-producing and military services companies in the world, 2018 (in millions of US dollars)

\begin{tabular}{|c|l|c|c|c|}
\hline $\begin{array}{c}\text { Rank- 2018 } \\
(\mathbf{2 0 1 7})\end{array}$ & \multicolumn{1}{|c|}{ Company } & $\begin{array}{c}\text { Arms sales } \\
\mathbf{( 2 0 1 8 )}\end{array}$ & $\begin{array}{c}\text { Total sales } \\
\mathbf{( 2 0 1 8 )}\end{array}$ & $\begin{array}{c}\text { Arms sales as a \% } \\
\text { of total sales (2018) }\end{array}$ \\
\hline $9(10)$ & Almaz-Antey & 9640 & 9872 & 98 \\
\hline $15(14)$ & United Aircraft Corp. & 5420 & 6563 & 83 \\
\hline $18(15)$ & United Shipbuilding Corp. & 4700 & 5565 & 84 \\
\hline $26(24)$ & Tactical Missiles Corp. & 3600 & 3668 & 98 \\
\hline $33(32)$ & United Engine Corp. & 2950 & 3904 & 76 \\
\hline $40(35)$ & High Precision Systems & 2630 & 2711 & 97 \\
\hline $45(43)$ & Russian Electronics & 2330 & 2668 & 87 \\
\hline $52(37)$ & Russian Helicopters & 1810 & 3006 & 60 \\
\hline $53(46)$ & KRET & 1770 & 1931 & 92 \\
\hline $64(68)$ & UralVagonZavod & 1370 & 2209 & 62 \\
\hline
\end{tabular}

Source: SIPRI (2021)

In order to assess the prospects for maintaining and strengthening the positions of Russian military companies in world rankings, we decided to analyze the dynamics of changes in their financial indicators over ten years (2009-2018) (see Table 3). ${ }^{\dagger}$

Table 3. Dynamics of the main financial indicators of the largest corporations of the Russian militaryindustrial complex from 2009 to 2018, in million rubles

\begin{tabular}{|l|r|r|r|r|r|r|r|r|r|r|}
\hline \multirow{2}{*}{ Corpor. } & \multicolumn{2}{|c|}{ Equity } & \multicolumn{2}{c|}{ Total assets } & \multicolumn{2}{c|}{ Revenue } & \multicolumn{2}{c|}{ Net profit } & \multicolumn{2}{c|}{$\begin{array}{l}\text { Long term } \\
\text { duties }\end{array}$} \\
\cline { 2 - 11 } & $\mathbf{2 0 0 9}$ & $\mathbf{2 0 1 8}$ & $\mathbf{2 0 0 9}$ & $\mathbf{2 0 1 8}$ & $\mathbf{2 0 0 9}$ & $\mathbf{2 0 1 8}$ & $\mathbf{2 0 0 9}$ & $\mathbf{2 0 1 8}$ & $\mathbf{2 0 0 9}$ & $\mathbf{2 0 1 8}$ \\
\hline $\begin{array}{l}\text { Rostec } \\
\text { Corp. }\end{array}$ & $250,025.5$ & $1,266,395.8$ & $255,132.6$ & $1,273,892.9$ & 111.0 & $2,833.9$ & 70.2 & $130,231.6$ & $3,663.8$ & 638.1 \\
\hline $\begin{array}{l}\text { Russian } \\
\text { Helicopters }\end{array}$ & 323.8 & $90,523.3$ & $2,412.3$ & $154,852.0$ & 775.7 & $35,528.5$ & 271.0 & $19,966.7$ & $1,585.2$ & $23,793.4$ \\
\hline $\begin{array}{l}\text { United } \\
\text { Engine C. }\end{array}$ & 129.7 & $203,126.8$ & 185.9 & $309,837.1$ & $3,998.2$ & $42,185.0$ & 106.1 & $7,737.2$ & .107 & $41,678.8$ \\
\hline $\begin{array}{l}\text { High } \\
\text { Precision } \\
\text { Systems }\end{array}$ & 14.4 & $70,070.7$ & 16512 & $71,596.8$ & 13.7 & $8,607.9$ & -.646 & $5,525.0$ & 0 & 1.5 \\
\hline KRET & 15.0 & $75,973.9$ & 14.6 & $101,771.4$ & 0 & $28,714.2$ & -1.277 & $7,960.2$ & 0 & $6,668.1$ \\
\hline UAC & $146,578.7$ & $310,226.3$ & $171,085.4$ & $468,790.8$ & $3,414.6$ & $52,678.3$ & $-10,067.7$ & $-29,995.3$ & $17,597.5$ & $56,460.8$ \\
\hline USC & $117,128.4$ & $249,827.5$ & $136,277.1$ & $795,157.2$ & 104.0 & $61,996.0$ & 96.2 & 294.6 & $11,624.8$ & $492,015.2$ \\
\hline $\begin{array}{l}\text { Almaz- } \\
\text { Antey }\end{array}$ & $50,542.2$ & $\begin{array}{l}12,789,8 \\
(2016)\end{array}$ & $82,622.9$ & $408,203.0$ & $15,889$. & $212,439.1$ & $1,181.9$ & $1,125.3$ & $1,846.0$ & $66,963.4$ \\
\hline $\begin{array}{l}\text { Tactical } \\
\text { Missiles C. }\end{array}$ & $26,098.2$ & $\begin{array}{l}76,268.3 \\
(2016)\end{array}$ & $34,574.8$ & $136,632.5$ & $8,291.8$ & $26,839.1$ & 492.9 & $1,321.8$ & $3,454.6$ & $16,077.0$ \\
\hline
\end{tabular}

Source: according to SPARK-INTERFAX (2020)

The largest Russian military-industrial company in Russia is undoubtedly the state corporation Rostec. At the moment, she has prepared a development strategy until 2025, the tasks of which are to enter the ten largest world industrial corporations in terms of revenue; an increase in the share of civilian products in revenue above $50 \%$; financing of the investment program primarily at the expense of its own funds, as well as borrowed funds; raising labor productivity to the level of the best quarter of the world's players.

${ }^{\dagger}$ The limited volume of the article does not allow citing data for all years of the specified period. For Rosteh, the latest available data for 2017, for Almaz-Antey and Tactical Missiles Corp. for 2016 
At the beginning of 2009, the value of the corporation's assets was estimated at 255.13 billion rubles. After 9 years, Rostec's assets increased to 1.27 trillion. rubles, which is 5 times higher than in 2009. At first glance, the dynamics of the corporation's revenue and net profit may seem strange. We can notice a positive trend in net profit that is several times higher than the corporation's revenue. Note, however, that we are analyzing unconsolidated financial statements. For many years, Rostec received net profit mainly from income from participation in other organizations, other income, and financial investments. Since 2014, the corporation, which includes a huge number of different structures, has increased its net profit by 7 times.

With regard to the efficiency of using equity capital and the financial stability of the company, two indicators were considered: return on equity (indicates how effectively equity capital is used, that is, how much profit was generated for each ruble of borrowed equity) and financial leverage (an indicator indicating change in debt burden). We can see that since 2012 Rostec has been pursuing a policy of reducing its debt burden, as well as increasing the return on its own funds, which increases the financial strength and stability of the company (see fig. 1).

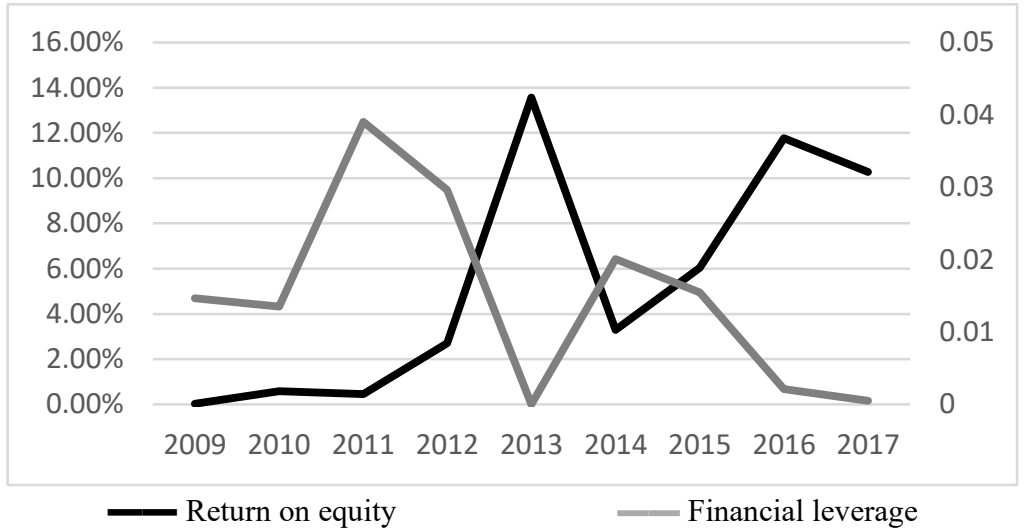

Figure 1. Return on equity and Financial leverage of Rostec, $\%$ and units

Source: according to SPARK-INTERFAX (2020)

We analyzed the changes in the indicators of the financial condition of all Russian military-industrial companies presented in table. 3 for the specified period. However, the limited scope of this article does not allow us to present all the results obtained. Therefore, we are forced to confine ourselves to considering the financial situation of only two industry corporations that were in the TOP-25 from SIPRI in 2019. We are talking about the companies Almaz-Antey and United Shipbuilding Corporation".

Concern Almaz-Antey was established in 2002 and became the first large holding, created within the framework of the federal target program "Reforming and development of the military-industrial complex in the period 2002-2006". It includes enterprises that develop and produce weapons for air defense and missile defense. In the period from 2003 to 2016, the total value of the group's assets increased 5 times. Over the entire period under review, one can observe a stable growth in the group's revenue, which cannot be said about net profit. For 8 years, revenue increased 13 times and in 2016 amounted to 212.44 billion rubles. Throughout the entire period, the corporation did not go into a loss-making state. In 2016, there was a sharp decline in net profit by $95 \%$. To a greater extent, this is due to the fact that the cost of sales, administrative and other expenses have increased, and other income of the concern has also decreased by more than 2 times. In this regard, we can observe a drop in the return on equity for 2016 (see fig. 2). 


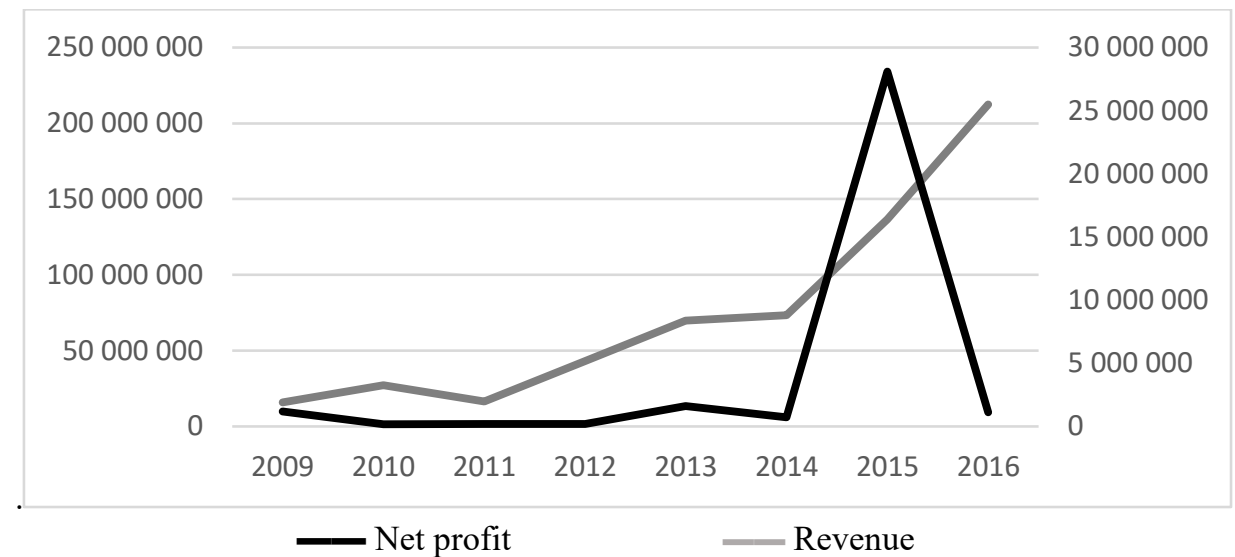

Figure 2. Revenue and net profit (loss) of Almaz-Antey, thousand rubles

Source: according to SPARK-INTERFAX (2020)

As for the debt burden of the corporation, it can be noted that it was in a very unstable state and by 2016 reached the peak of long-term debt (see fig. 3).

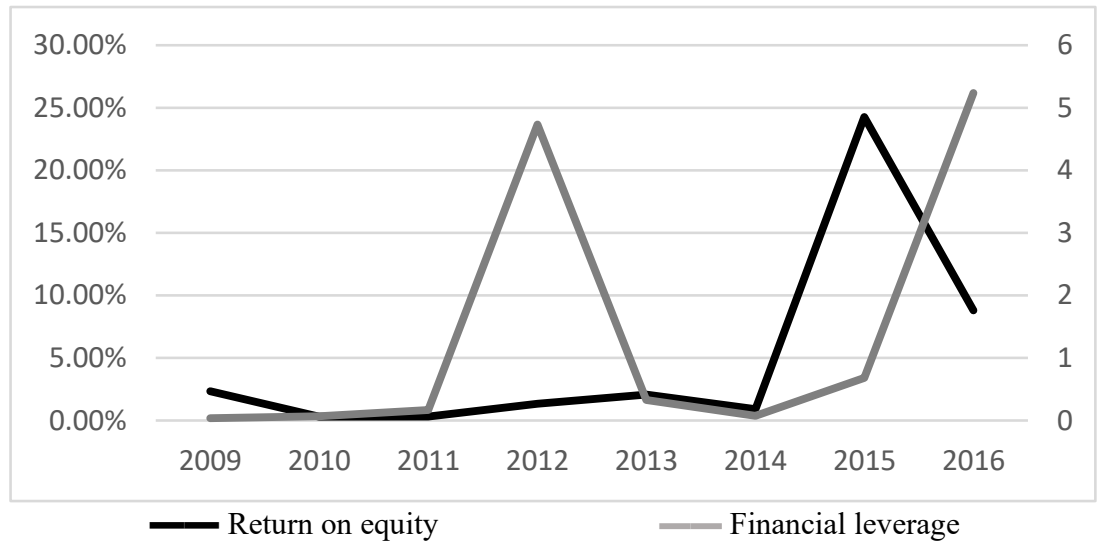

Figure 3. Return on equity and financial leverage of Almaz-Antey, $\%$ and units.

Source: according to SPARK-INTERFAX (2020)

United Shipbuilding Company was established in 2007 and currently includes most of the shipbuilding defense enterprises in Russia. It is important to note that $100 \%$ of shares of JSC USC are in federal ownership represented by the Federal Property Management Agency. The corporation was created in order to develop the scientific and production potential of the defense industry, to ensure the security and defense of the state, to concentrate intellectual, industrial and financial resources for the implementation of projects for the construction of warships, the development of civil shipbuilding, as well as the development of the continental shelf and the world maritime market. USC has developed a development strategy until 2030, according to which it is necessary to achieve the following goals: fulfillment of the state defense order and the state armament program in a timely manner; ensuring the competitiveness of Russian-made ships and equipment in terms of technical and financial indicators; increasing the level of quality of production of marine technology, corresponding to the world level.

The value of the corporation's assets for the period 2009-2018 increased by 5.8 times. For 2018 , their cost is 795.16 billion rubles. In general, we can observe a stable growth in the 
corporation's revenue, which increased 596 times over the 10 years under review, and increased by $38.52 \%$ over the period 2017-2018. Despite this, JSC "USC" in some periods of its activity was in a loss-making state. For example, one of the factors behind the sharp decline in profits in 2016-2017 by an average of 70\% is an increase in the cost of sales of products in 2 times. By 2018, the corporation has tripled its net profit compared to 2009 (see fig. 4).

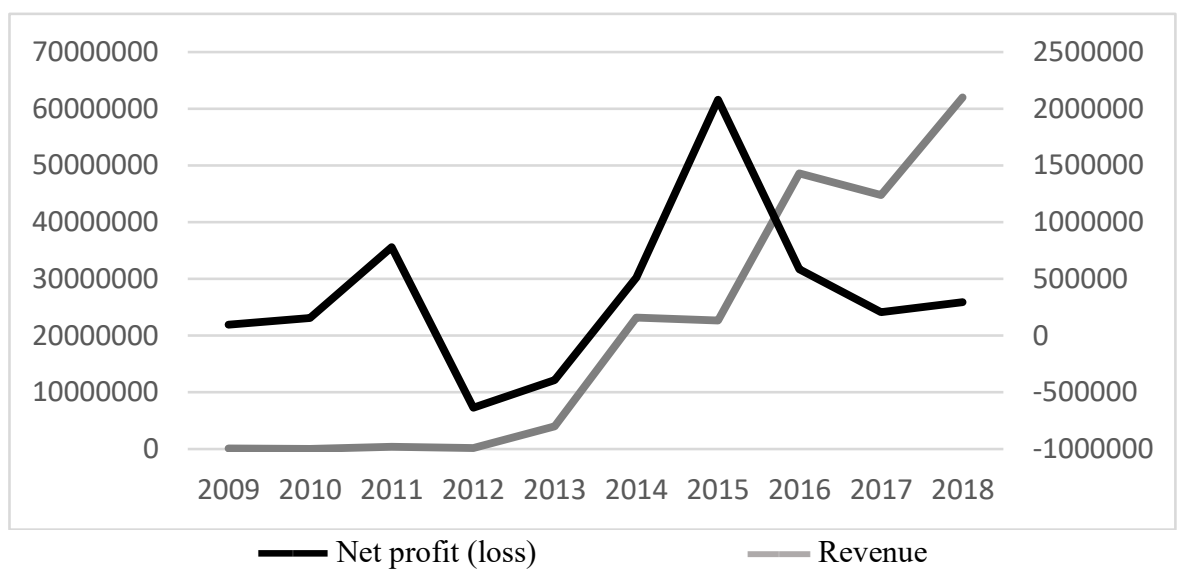

Figure 4. Revenue and net profit (loss) of JSC USC, thousand rubles

Source: according to SPARK-INTERFAX (2020)

Also, note that the corporation has been increasing its debt burden for 10 years. With regard to the return on equity, then, given the uneven growth of net profit and the corporation being in a loss-making state for two years (2012-2013), we can conclude that equity capital was not used effectively enough (see fig. 5).

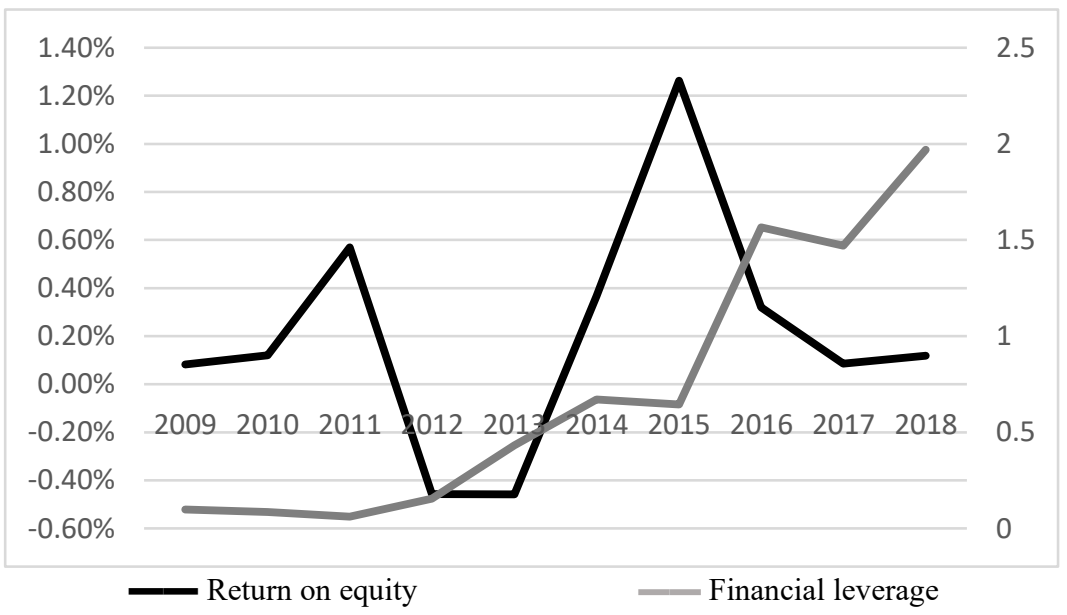

Figure 5. Return on equity and financial leverage of JSC "USC", \% and units

Source: according to SPARK-INTERFAX (2020)

\section{Discussion and Conclusions}

The global arms trade is undergoing certain changes. Although the leading exporters generally retain their leading positions, new players such as China, UAE, South Korea, Saudi Arabia and some others are trying to squeeze them out. You cannot become a serious player 
in this market without creating large national or even transnational companies. The leading three (USA, Russia, EU) in order to maintain and, if possible, strengthen their positions in the arms export market, have to seriously reform their military-industrial complex and look for ways to increase the efficiency of companies producing military products (Bellais, 2021; Kim and Hong, 2015).

Despite the presence of certain problems in the functioning of the Russian militaryindustrial complex (Gregova et al., 2021), overall, the recent reforms carried out can be considered successful. During the period under review, most of the companies in the Russian defense industry have shown cumulative growth in financial performance. Absolutely all corporations have positive dynamics in increasing the value of their assets. Most of them demonstrate stable growth in net profit and revenue. The growth is especially noticeable since 2013-2014, which is reflected in the implementation of the State Armaments Program - 2020. However, it is worth mentioning the fact that a certain share of corporations is experiencing an increase in debt burden and a decrease in the return on equity, which in turn affects the financial stability and efficiency of using the equity capital of corporations for the worse (Dengov \& Tulyakova, 2015a,b,c).

\section{References}

1. Bedenel, A. L., Jourdan, L., \& Biernacki, C. (2019). Probability estimation by an adapted genetic algorithm in web insurance. In R. Battiti, M. Brunato, I. Kotsireas, \& P. Pardalos (Eds.), Lecture notes in computer science: Vol. 11353. Learning and intelligent optimization (pp. 225-240). Springer.

2. Bellais, R. (2021). MBDA's Industrial Model and European Defence. Defence and Peace Economics, Early Access: JUN 2021.

3. Bitzinger, R. (2016). Reforming China's defense industry. Journal Of Strategic Studies, 39(5-6), SI, 762-789.

4. Blom, M., Castellacci, F., \& Fevolden, A. (2014). Defence firms facing liberalization: innovation and export in an agent-based model of the defence industry. Computational and Mathematical Organization Theory, 20(4). 430-461.

5. Blum, J. (2019). Arms production, national defense spending and arms trade: Examining supply and demand. European Journal of Political Economy, 8, Article 101814.

6. DEFENCE NEWS (2021, July 7). Top 100 for 2020. https://people.defensenews.com/top-100/

7. Dengov, V., \& Tulyakova, I. (2015a). Credit Risk Analysis for the Telecommunication Companies of Russia: Problem Statement and Selection of Indicators. 2nd International Multidisciplinary Scientific Conference on Social Sciences and Arts, SGEM 2015: Political Sciences, Law, Finance, Economics and Tourism, VOL II, 131-138.

8. Dengov, V., \& Tulyakova, I. (2015b). Credit Risk Analysis for the Telecommunication Companies of Russia: Statistical Model. 2nd International Multidisciplinary Scientific Conference on Social Sciences and Arts, SGEM 2015: Political Sciences, Law, Finance, Economics and Tourism, VOL II, 139-146.

9. Dengov, V., \& Tulyakova, I. (2015c). Credit Risk Analysis for the Telecommunication Companies of Russia: Fuzzy Model. Comparison of the Results. 2nd International Multidisciplinary Scientific Conference on Social Sciences and Arts, SGEM 2015: Political Sciences, Law, Finance, Economics and Tourism, VOL II, 123-130.

10. Dengov, V., Tulyakova, I., \& Gregova, E. (2018). Military-Technical Cooperation of Russia in the Context of Globalization: Experience of Cooperation with China. In $\mathrm{T}$. 
Kliestik (Ed.). Globalization and its Socio-Economic Consequences, 16th International Scientific Conference Proceedings, PTS I-VI, 78-86.

11. Dengov, V., Tulyakova, I., \& Gregova, E. (2021). Positions and prospects of Russian shipbuilding in the world market of naval equipment. In T. Kliestik (Ed.), SHS Web of Conferences: Vol. 92. Article 08007.

12. Fleurant, A., \& Tian, N. (2018). SIPRI's arms producing and military services companies database. Economics of Peace and Security Journal, 13(2), 5-10.

13. Gregova, E., Tulyakova, I., \& Dengov, V. (2021). Actual problems and limiting factors in the development of the Russian military-industrial complex. In T. Kliestik (Ed.), SHS Web of Conferences: Vol.92. Article 07021

14. Kim J. Y., \& Hong J. Y. (2015). The framework for analyzing the efficiency of global arms-producing and military services companies based on DEA-AR and ANP. International Journal of Applied Engineering Research, 10(10), 27111-27120.

15. SIPRI (2021, July 6). SIPRI Arms Industry Database. https://www.sipri.org/databases/ armsindustry

16. SPARK-INTERFAX (2020, July 6). https://spark-interfax.ru/\#_top

17. Tulyakova, I. (2016). The United States and Russia on the Global Arms Markets. In T. Kliestik (Ed.). Globalization and its Socio-Economic Consequences, 16th International Scientific Conference Proceedings, PTS I-V, 2236-2244.

18. Tulyakova, I., \& Dengov, V. (2018). Military-Technical Cooperation of Russia in the Context of Globalization: Experience of Cooperation with India. In T. Kliestik (Ed.), Globalization and its Socio-Economic Consequences, 16th International Scientific Conference Proceedings, PTS I-VI, 1401-1408.

19. Tulyakova, I., Dengov, V., \& Gregova, E. (2019). The Positions of Russia and Croatia Shipbuilding Products on World Markets and Prospects of Co-Operation (Analytical Overview). Nase More, 66(3S), 13-21.

20. Tulyakova, I., Gregova, E., \& Dengov, V. (2017). Assessment of Competitiveness of Shipbuilding Industry in Russia. Nase More, 64(3), 112-119.

21. Wang, K-H., Su, C-W., Tao, R., \& Chang, H.L. (2019). Does the Efficient Market Hypothesis Fit Military Enterprises in China? Defence and Peace Economics, 30(7), 877-889. 